\title{
Tongkol (Euthynnus Affinis) Fermented on Organoleptics and Organic Acid Production
}

\author{
Ni Made Darmadi ${ }^{*}$, Dewa Gede Semara Edi ${ }^{2}$, Made Kawan ${ }^{3}$ \\ Management of Aquatic Resources, Faculty of Agriculture, Universitas Warmadewa, Denpasar, Bali- \\ Indonesia \\ \{madedarmadi240466@gmail.com¹,dewagedesemaraedi65@gmail.com²,imadekawan@yahoo.co.id³
}

\begin{abstract}
Fermentation is a type of processing and preservation of fish which has a very unique process to produce flavor and longevity. With fermentation, simple compounds are formed so that they are more easily absorbed by the human body. Fermented products include food that is safe for consumption. Tongkol fish whose availability in the market is quite a lot can be used as fermented tuna to diversify processed fish. The research objective was the creation of fermentation technology with the best fermentation of the three types of fermentation used as treatment so as to create a new innovative product of fermented tuna with the best Organoleptic Value and Organic Acid. The study used an experimental method with a completely randomized design (CRD) with three treatments and three repetitions each, after which data analysis was performed using ANOVA with the LSD test. The results showed that the combination of Fermen Bromelin 50\% with Papain 50\% produced the best Organoleptic with Lactic Acid Value of 2,720\%, Acetic Acid 1,810 and Butyric Acid 2,767\%. With Preferred Organoleptic value (6).
\end{abstract}

Keywords: Tuna; Fermentation; Lactic Acid Bacteria.

\section{Introduction}

Tongkol fish, including small pelagic fish, have a high enough protein content. Including economically important fish so that its existence in the market is always there (Field Surve). In the general market, Tongkol Fish in processed form are only found in the form of Smoke and Pindang, so it is necessary to find an alternative technology to make processed Tongkol fish. To increase the consumption of Tongkol fish, it is necessary to be innovative to change the shape or taste of the fish. According to [1] opinion, it is said that there is a need to find new foodstuffs or develop foodstuffs for food diversification.

Fermentation is an alternative for tuna diversification. Fermentation technology is a technology that is easy to apply, easy and safe to consume, has a long enough shelf life. According to [2] the final fermentation product usually contains compounds that are simpler and easier to digest than the original material. It is further stated that fermentation also functions as a method of processing in the context of preserving materials and ways to reduce and even eliminate toxic substances contained in a material and their presence. various types of microorganisms that have the ability to convert starch into protein by adding inorganic nitrogen through fermentation. Fermentation basically occurs due to micro-activity in a suitable organic substrate, the occurrence of this fermentation can cause changes in initial 
properties, which are caused by the breakdown of some of the initial ingredients so that they become simpler components [3].

This study included spontaneous fermentation because there was no addition of an external starter culture [4]. The purpose of this study was to find the type of ferment that can produce the best Tongkol (Euthynnus affinis) in terms of organoleptic and organic acids formed. The benefits to be achieved from this research are: From an academic point of view, new knowledge is obtained as information and in terms of fish farmers, they will get new types of processed products that can be developed in the community with the hope of increasing income.

\section{Literature Review}

\subsection{Description and Classification of Tuna Fish (Euthynnus afinnis)}

According to [5] the structure of Tongkol fish consists of red meat which contains 71$76.7 \%$ water, $21.6-26.3 \%$ protein and $1.3-2.1 \%$ fat.

Furthermore, the Classification of Tuna Fish (Euthynnus affinis) is as follows:

- Phylum: Chordata

- Class: Teleostei

- Order: Perchomorphi

- Sub Order: Scombridae

- Familiy: Scombridae

- Genus: Euthynnus

- Species: Euthynnus affinis

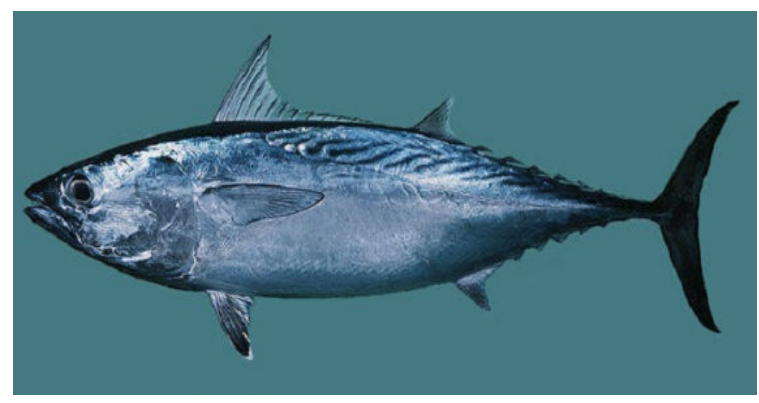

Figure. 1. Tuna Fish (Euthynnus affinis)

\subsection{Fermentation}

Boiotechnology is a branch of science that is currently experiencing rapid development. Along with the need for warmth, medicine, cosmetics, continuously making biotechnology as the solution [6].

Food biotechnology is defined as the application of biological techniques to the products of food crops, foods and microorganisms with the aim of improving the properties, quality, safety and convenience of food processing and production [7]. Biotechnology is Traditional and Modern, Traditional Products for example, Making Tempe, Terasi, Peda, Bacem, Bakasang, Fish Soy Sauce, etc., while Modern Biotechnology is like Cheese, Enzymes, Yogurt, Yakult, Genetically Engineered Products. 
Fermentation occurs on the organic substrate, as a result of the fermentation process changes the initial properties of the material due to the changing of the organic material into simpler rental compounds [3]. In the fermentation process the fat content contained in fish will be broken down into free fatty acids and glycerol, and further broken down into ketone and 3 aldehyde compounds which are the cause of a distinctive odor, so fermented products will always have a distinctive smell and taste [8] ].

In microbial fermentation that plays a role is Lactic Acid Balteri. With this bacterial activity, it can convert sugar / carbohydrates into lactic acid and other organic acids. There are two types of fermentation pathways namely Homofermentative and Heterofermentative. Homofermentative means that Lactic Acid Bacteria are able to convert sugar / carbohydrates into $80 \%$ lactic acid while heterofermentative, lactic acid bacteria are able to convert sugar / carbohydrates into 50\% lactic acid and 50\% in the form of acetic acid, ethanol and carbon dioxide [9].

\subsection{Pineapple, Papaya}

Pineapple is a fruit that is always there throughout the year, so that the Bromelin enzyme from pineapple can be obtained easily [10]. Bromelin is a protease enzyme that can degrade meat collagen, so it can tenderize meat [10].

The parts of the papaya tree are very useful. The stems, leaves, and fruit of young papaya contain white sap. This sap contains an enzyme that breaks down proteins or a proteolytic enzyme called papain. can be used for various purposes, including beer purification, meat tenderizer, raw material for the leather tanning industry, as well as being used in the pharmaceutical and cosmetic (beauty) industries [11]. Papain enzyme works more actively on vegetable protein while bromelin works more actively on animal protein.

Papain relatif tahan terhadap suhu, bila dibandingkan dengan enzim proteolitik lainnya seperti bromelin dan lisin. Enzim papain lebih tahan terhadap suhu tinggi dibanding dengan enzim bromelin [10].

\section{Research Methods}

\subsection{Place and Time of Research}

The research was carried out in three places, namely the Laboratory of the Faculty of Agriculture, Warmadewa University for the manufacture of products and organoleptics. Laboratory of Food Analysis, Faculty of Agricultural Technology, Udayana University for Organic Acid analysis.

\subsection{Research Methods}

In this study using an experimental method using a completely randomized design with a single factor, namely the use of three types of fermen. The three types of Fermen used were: Treatment A = Bromelin Enzyme (Fresh Pineapple Fruit), Treatment B = Papain Enzyme (Fresh Young Papaya Fruit) and the third Treatment $\mathrm{C}=50 \%$ Bromelin with $50 \%$ Papain ... times, after that tabulated the data, analyzed the data statistically using ANOVA with further tests using BNT (Least Significant Difference).

\subsection{Research Implementation}

Research implementation: 
- Prepare tuna fish of the same size. The freshness is the same, the fish is bought at the same place.

- Preparing three types of fermen that will be used: Pineapple Fruit, Papaya Fruit, Combination of 50\% Pineapple Fruit and 50\% Papaya

- Prepare all research supporting tools and materials.

- Carry out research according to treatment

- Perform fermentation for four (4) days

- Analyze Samples

- Data tabulation and data analysis.

The Research Flow Chart can be seen below

Preparing the fish that will be used according to the criteria, Preparing all the ingredients to be used, preparing the tools to be used, fermenting with three types of fermentation for 4 days (starting from day 0 )

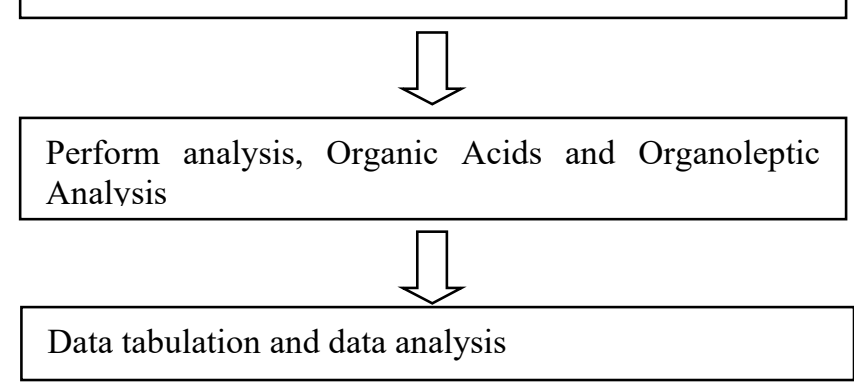

Figure. 2. Flowchart of Research Implementation

\subsection{Data Analysis}

The data obtained from the research results are then processed with statistical product and service solutions (SPSS) 17 for windows, as follows:

- To see the effect of the treatment, an Anova test was performed

- If there are differences between the treatments in the ANOVA test, then proceed with the LSD further test (Least Significant Difference) to see the effect between treatment units.

Table 1. Hedonic Scale and Numeric Scale (For Organoleptic Analysis)

\begin{tabular}{lc}
\hline \multicolumn{1}{c}{ Hedonic Scale } & Numeric Scale \\
\hline Really like & 7 \\
Like it & 6 \\
Kind of like it & 5 \\
The usual & 4 \\
I don't like it & 3 \\
Do not like & 2 \\
Very dislike 7 & 1 \\
\hline
\end{tabular}




\section{Results and Discussion}

\subsection{Organic and Organoleptic Acid Test Results}

Table 2. Average Value of Organic and Organoleptic Acid Test

\begin{tabular}{ccccc}
\hline Factor 1 & $\begin{array}{c}\text { Butiric Acid } \\
(\mathbf{\%})\end{array}$ & Acetic Acid & $\begin{array}{c}\text { Lactic Acid } \\
(\mathbf{\%})\end{array}$ & Organoleptic test \\
\hline A & 2.910 & 1.980 & 2.970 & 5 (Kind of like it) \\
B & 1.933 & 1.310 & 1.970 & 5 (kind of like it) \\
C & 2.767 & 1.810 & 2.720 & 6 (like) \\
Fresh Fish & 0.95 & 0.64 & 0.97 & \\
\hline
\end{tabular}

$\mathrm{A}=$ Bromelin

$\mathrm{B}=$ Papain

C $-50 \%$ Bromelin with $50 \%$ Papain

\subsection{Lactic Acid Analysis}

Table 2. Checklist of Variety of Lactic Acid

\begin{tabular}{ccccccc}
\hline $\begin{array}{c}\text { Religious } \\
\text { Resources }\end{array}$ & Db & JK & KT & F count & F 5\% & F 1\% \\
\hline Treatment & 2 & 1.626 & 0.813 & $12.84^{* *}$ & 5.14 & 10.92 \\
Random & 6 & 0.380 & 0.063 & - & - & - \\
Total & 8 & 2.006 & - & - & - & - \\
\hline
\end{tabular}

Table 3. Lactic Acid LSD Analysis

\begin{tabular}{ccccc}
\hline \multirow{2}{*}{ Treatment } & Average & $\mathbf{1}$ & $\mathbf{C}$ & $\mathbf{A}$ \\
& & $\mathbf{1 . 9 7 0}$ & $\mathbf{2 . 7 2 0}$ & $\mathbf{2 . 9 7 0}$ \\
\hline $\mathrm{B}$ & 1.970 & - & - & - \\
$\mathrm{C}$ & 2.720 & 0.750 & - & - \\
$\mathrm{A}$ & 2.970 & 1.000 & 0.250 & - \\
\hline
\end{tabular}

Table 4. Lactic Acid LSD Notation

\begin{tabular}{ccc}
\hline Treatment & Average & Notation \\
\hline B & 1.970 & $\mathrm{a}$ \\
C & 2.720 & $\mathrm{~b}$ \\
$\mathrm{~A}$ & 2.970 & $\mathrm{c}$ \\
\hline
\end{tabular}

4.2. Analysis of Acetic Acid

Table 5. Checklist of Variety of Acetic Acid

\begin{tabular}{ccccccc}
\hline $\begin{array}{c}\text { Religious } \\
\text { Resources }\end{array}$ & Db & JK & KT & F count & F 5\% & F 1\% \\
\hline Treatment & 2 & 0.728 & 0.364 & $117.39^{* *}$ & 5.14 & 10.92 \\
Random & 6 & 0.019 & 0.003 & - & - & - \\
\hline
\end{tabular}




\begin{tabular}{cccccc}
\hline Total & 8 & 0.746 & - & - & - \\
\hline \multicolumn{7}{c}{ Table 6. Acetic Acid LSD Analysis } \\
\cline { 2 - 6 } & \multirow{2}{*}{ Treatment } & Average & $\mathbf{B}$ & $\mathbf{C}$ & $\mathbf{A}$ \\
& & $\mathbf{1 . 3 1 0}$ & $\mathbf{1 . 8 1 0}$ & $\mathbf{1 . 9 8 0}$ \\
\hline B & 1.310 & - & - & - \\
C & 1.810 & 0.500 & - & - \\
A & 1.980 & 0.670 & 0.170 & - \\
\hline
\end{tabular}

Tabel 7. Acetic Acid LSD Notation

\begin{tabular}{ccc}
\hline Treatment & Average & Notation \\
\hline $\mathrm{B}$ & 1.310 & $\mathrm{a}$ \\
$\mathrm{C}$ & 1.810 & $\mathrm{~b}$ \\
$\mathrm{~A}$ & 1.980 & $\mathrm{c}$ \\
\hline
\end{tabular}

\subsection{Butyric Acid Analysis}

Table 8. Checklist of Variety of Butiric Acid

\begin{tabular}{ccccccc}
\hline Religious Resources & db & JK & KT & F count & F 5\% & F 1\% \\
\hline Treatment & 2 & 1.671 & 0.836 & $244.47^{* *}$ & 5.14 & 10.92 \\
Random & 6 & 0.021 & 0.003 & - & - & - \\
Total & 8 & 1.692 & - & - & - & - \\
\hline
\end{tabular}

Tabel 9. Butiric Acid LSD Analysis

\begin{tabular}{ccccc}
\hline \multirow{2}{*}{ Treatment } & Average & $\mathbf{B}$ & $\mathbf{C}$ & $\mathbf{A}$ \\
& & $\mathbf{1 . 9 3 3}$ & $\mathbf{2 . 7 6 7}$ & $\mathbf{2 . 9 1 0}$ \\
\hline B & 1.933 & - & - & - \\
C & 2.767 & 0.834 & - & - \\
A & 2.910 & 0.977 & 0.143 & - \\
\hline
\end{tabular}

Tabel 10. Butiric Acid LSD Notation

\begin{tabular}{ccc}
\hline Treatment & Average & Notation \\
\hline $\mathrm{B}$ & 1.933 & $\mathrm{a}$ \\
$\mathrm{C}$ & 2.767 & $\mathrm{~b}$ \\
$\mathrm{~A}$ & 2.910 & $\mathrm{c}$ \\
\hline
\end{tabular}

In fermentation products, organic acids will always be formed which is the result of the activity of Lactic Acid Bacteria. The results showed that the treatment had a very significant effect on the formation of lactic acid, acetic acid and butyric acid. For the value of lactic acid, acetic acid and butyric acid can be seen in Table 4.1. It can be seen that there is an increase in the value for the three types of organic acids above when compared to the value of organic acids in fresh tuna, it can be seen in Table 4.1.

Types of Lactic Acid Batteries found in fermented Cob is heterofermentative, it is proven that organic acids other than lactic acid and lactic acid do not dominate the amount in this treatment. The fermentation process is homofermentative if it only produces lactic acid (80\%) or it dominates [9]. Heterofermentative fermentation produces a mixture of various compounds or other components, for example acetate, ethanol, carbon dioxide, and lactic acid. 
It is also said that fermentation can grow acid-forming microbes and alcohol and suppress the growth of proteolytic and lipolytic microbes [12].

\section{Conclusions}

From this research it can be concluded that the best treatment is treatment $\mathrm{C}$, namely the use of fermen $50 \%$ Bromelin with $50 \%$ papain with results of lactic acid 2,720, acetic acid 1,810 and butyric acid 2,767 with a value of Organoleptic Favored (Value 6).

\section{Reference}

[1] Muthmainna, S. M. Sabang, and Supriadi, "Pengaruh Waktu Fermentasi Terhadap Kadar Protein Dari Tempe Biji Buah Lamtoro Gung (Leucaena leucocephala)," $J$. Akad. Kim., vol. 5, no. 1, pp. 50-54, 2016.

[2] L. Sari and T. Purwadaria, "Pengkajian Nilai Gizi Hasil Fermentasi Mutan Aspergillus nigerpada Substrat Bungkil Kelapa dan Bungkil Inti Sawit," Biodiversitas, vol. 5, no. 2, pp. 48-51, 2004.

[3] N. I. Sari, Dahlia, and D. Octavian, "Quality Characteristics Fermented Tilapia (Oreochromis Niloticus) Different Carbohydrate Source," J. Perikan. dan Kelaut., vol. 18, no. 2, 2013.K. Waty, E. Purwijantiningsih, and S. Pranata, "Kualitas Fermentasi Spontan Wadi Ikan Patin (Pangasius Sp.) dengan Variasi Konsentrasi Garam," J. Biota, vol. 4, no. 1, pp. 24-32, 2019.

[4] S. S. Yuwono, "Ikan Tongkol (Euthynnus affinis)," Univ Brawijaya, 2015.

[5] H. D. Faridah, and S. K. Sari, "Utilization Of Microorganism On The Development Of Halal Food Based On Biotechnology," J. of Halal Product and Research, vol. 2, no. $1,2019$.

[6] A. Pramashinta, L. Riska, and Hadiyanto, "Bioteknologi Pangan: Sejarah, Manfaat dan Potensi Resiko," J. Aplikasi Teknologi Pangan, vol. 3, no. 1, pp. 1-5, 2014

[7] N. Ahillah, A. Rusdanillah, W. Afiana, R. Sulistiani, and R. P. L. Mail, "The Influence Of Salt Concentration On The Fermentation Of The Wader Fish (Rasbora Lateristriata)," Bioedukasi, vol. 10, no. 2, pp.12-17, 2017

[8] Desniar, "Karakterisasi Bakteri Asam Laktat Dari Produk Fermentasi Ikan (Bekasam) ," Des Pascasarjana Institut Pertanian Bogor, 2012.

[9] D. P. Utami, Pudjomartatmo, and A. M. P. Nuhriawangsa, "Manfaat Bromelin dari Ekstrak Buah Nanas (Ananas comosus L. Merr) dan Waktu Pemasakan untuk Meningkatkan Kualitas Daging Itik Afkir," J. Sains Peternakan, vol. 9, no. 2, 2011

[10] A. M. Farid, "Effectivityof Papaya Leaves (Caricapapaya L) As Inhibitor Of Aedes Aegypti Larvae," J. Majority, vol. 4, no. 5, 2015.

[11]D. I. W. Yanti, and F. A. Dali, "Characteristics of Lactic Acid Bacteria Isolated during Bakasang Fermentation Process,". J. Pengolahan Hasil Perikanan Indonesia, vol. 16, no. 2, 2013. 